\title{
TÜRK DİL KURUMUNUN SÜRELİ YAYINLARINDA YER ALAN SÖZLÜK BILİMI KONULU YAZILAR
}

\author{
Sami Baskın ${ }^{1} \quad$ Hilal Toker $^{2}$
}

Anahtar Kelimeler

Türk Dil Kurumu

Süreli Yayınlar

Sözlük Faaliyetleri

Sözlük Bilimi

Sözlük Bilimi Araştırmaları

\section{Makale Bilgisi}

Gönderim Tarihi: 20.04.2020

Kabul Tarihi: 03.06.2020

Elektronik Yayın Tarihi: 28.06.2019
Türkiye'de sözlük faaliyetlerini düzenli olarak yürüten en eski kurum Türk Dil Kurumudur. Kurumun kurulduğu yıldan beri (1932) faaliyette olan bir Sözlük Bilim ve Uygulama Kolu adında bir birimi bulunmaktadır. Bu birim, sözlükle ilgili kuramsal ve uygulamalı çalışmaları ile Türk sözlükçülügünün yönünü belirlemiştir. Türk Dil Kurumunun sözlük faaliyetleri sadece sözlük hazırlamak (uygulama kısmı) ile sınırlı değildir. Kurumun yayımladığı süreli yayınlar (dergiler) vasıtasıyla sözlüğe dair tarihi, kuramsal bilgilerin yanında eleştiri, haber, tanıtım vb. türünden yazıları da sözlükle ilgilenenlere sunmaktadır. Bunlar incelendiğinde son asırdaki Türk sözlükçülüğünün gelişimi, sıklıkla ilgilendiği durumlar, sahadaki temel sorunlar gibi konuları açıklığa kavuşturmak mümkündür. Bu amaçla süreli yayımlarda yer alan sözlük ile ilgili yazılar dikkatle değerlendirilmelidir. Kurumun çevrimiçi sistemi ve 25.07.2019 tarihi itibariyle süreli yayınlarında toplam 21.430 yazı bulunmaktadır. Bunların sadece 272'si sözlüklerle ilgilidir. Yani sözlükle ilgili yazılar, toplam yazıların içerisinde sadece $\% 1.26$ oranında yer kaplamaktadır. Bu yazıların içerik analizleri yapıldığında da genellikle Türkçe Sözlük için kitaplardan yapılabilecek katkılar (sözcük ve cümle boyutunda alıntılar), yeni sözlük tanıtımları, yurt dışındaki sözlüklerle ilgili haberler, değerlendirme ve eleştirilerin yoğun biçimde işlendiği görülmüştür.

APA'ya göre alıntılama: Baskın, S. ve Toker, H. (2020). Türk Dil Kurumunun Süreli Yayınlarında Yer Alan Sözlük Bilimi Konulu Yazılar. Uluslararası Dil, Eğitim ve Sosyal Bilimlerde Güncel Yaklaşımlar Dergisi (CALESS), X(X), p-p.

Cited as (APA): Baskın, S., \& Toker, H. (2020). The urban fortune-tellers in the context of consumption. International Journal of Current Approaches in Language, Education and Social Sciences (CALESS), 2(1), 372-394.

\footnotetext{
${ }^{1}$ Doç. Dr., Tokat Gaziosmanpaşa Üniversitesi, Türkçe ve Sosyal Bilimler Eğitimi, Türkiye, samibaskin@gmail.com 2 Öğretmen, Atatürk Ortaokulu, Türkiye, crescent058@gmail.com
} 


\section{LEXICOGRAPHY ARTICLES IN PERIODICALS OF TURKISH LANGUAGE SOCIETY}

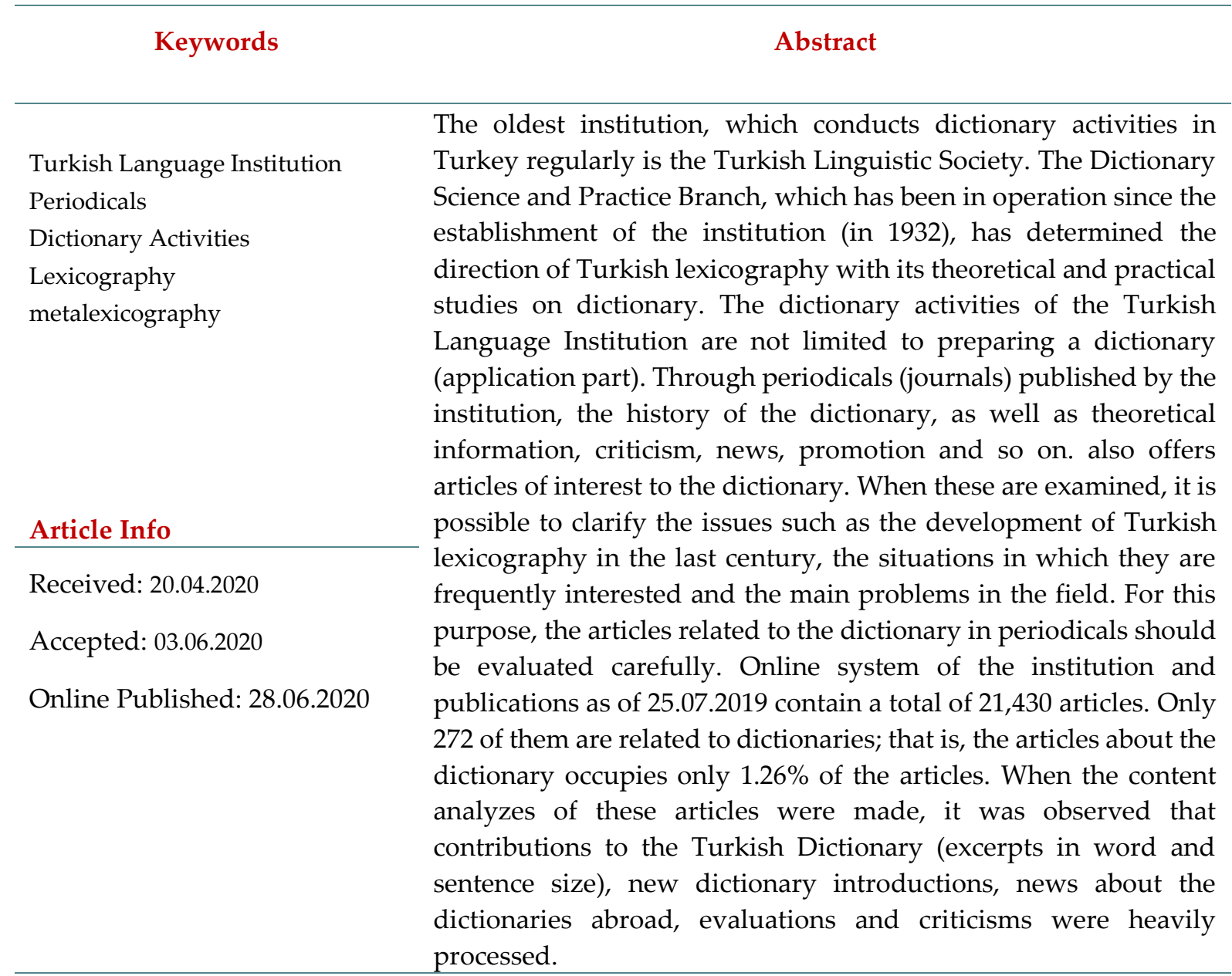

\section{Giriş}

Sözlüklerin geçmişi ile ilgili iki temel görüş vardır. Bunların ilkine göre sözlükler ilk kez, başka dilleri konuşan toplulukların dillerini anlamak için üretilmiştir. Crystal'a (2003) göre sözlüklerin bu ilk örneklerinin, "pratik bir amacı vardı. Çoğunlukla iki veya çok dilli olan sözcük listesi niteliğindeki sözlükler gezginlere, tacirlere veya misyonerlere yardımcı olmak amacıyla hazırlanmaktaydı. Eski Yunanda ise az kullanılan, tarihsel kaynaklarda kalmış, eskimiş ve unutulmuş sözcüklerle yerel sözcükleri veya teknik sözleri anlamak isteyen insanlara yararlı olmak üzere hazırlanan sözlükçeler 'glossary' vardı (Akt. Akalın, 2010: 270). Bu görüşe göre bilinen en eski sözlük Sümerce Akadca karşılıklar kılavuzu niteliğindeki Urra Hubullu'dur. Sözcüklerin konularına göre düzenlendiği sözlük, yirmi dört tabletten oluşmaktadır. Yaklaşık olarak MÖ 2300 yılında Akad İmparatorluğu'nda ortaya konulduğu sanılan sözlügün tabletleri Suriye'deki Ebla kalıntılarında bulunmuştur. Sözlük bugün 
Fransa'da Louvre Müzesi'ndedir (Akalın, 2010: 270 - 271). 1990'larda yapilan araştırmalara dayanan ikinci görüşe göre ise sözlüklerin geçmişini birkaç yüz yıl daha eskidir. Bu araştırmalara göre ilk sözlükler, başka dilleri anlamak için üretilmemiştir. Başkalarını anlamadan evvel milletlerin kendi kültürel varlıklarını muhafaza etme istekleri vardır. Sözlük, bu isteği gerçekleştirmek için üretilmiş bir koruma aracıdır. Bu yüzden ilk sözlüklerin geçmişini Antik Mısır'a veya daha eskisine dayandırmak mümkündür. Yani ilk sözlükler çok dilli değil, tek dillidir (Jackson, 2002).

İlk biçimleri ister tek dilli olsun isterse iki veya daha çok dilli olsun, tarih boyunca insanların kendi kültürel varlıklarını korumak, kendi dillerini öğretmek, başkalarının dilini anlamak vb. nedenlerden dolayı belli kurallarla inşa edilmiş sözlüklere ihtiyaçları olmuştur. Bu ihtiyaçlar, zaman içinde pek çok sözlük türünün ortaya çıkmasına neden olmuştur. Günümüzde cep sözlükleri, çocuk sözlükleri, e-sözlükler, genel sözlükler, terim sözlükleri, resimli sözlükler gibi hemen her biçimde ve her alanda bir sözlük bulmak mümkündür. Bu çeşitlilik sözlükler üzerine çalışan kurumların ortaya çıkmasına neden olmuştur. Günümüzde uluslararası boyutta hizmet eden sözlük kuruluşları bulunduğu gibi ulusal düzeyde sözlüklerle ilgilen kurumlar mevcuttur. Bu kurumların sözlüksel teoriler ve yöntemler geliştirmek; sözlüksel ürünlerle ilgili değişimleri takip etmek, hatta öncüsü olmak; yapılan çalışmaların eş güdümlü olmasını sağlamak; arz-talep dengesinin göz önünde bulundurarak uygun sözlüklerin üretilmesini sağlamak gibi temel hedefleri bulunmaktadır. Sözlüksel faaliyetlere öncülük eden bu kuruluşlardan uluslararası faaliyet gösterenlere European Association for Lexicography (EURALEX), Dictionary Society of North America (DSNA), African Association for Lexicography (AFRILEX), Asian Association for Lexicography (ASIALEX), Australasian Association for Lexicography (AUSTRALEX) gibi kurumları, ulusal boyutta hizmet edenlere de Southeast Asian Lexicography (SeaLex), Spanish Association for Lexicography (Fontenelle, 2008; Tono, 2014) gibi yerel örgütlenmeleri örnek olarak göstermek mümkündür. Bu kurumların her birinin kendine has sözlük bilimsel etkinlikleri, yayınları, üyelikleri mevcuttur. Örneğin EURALEX (Avrupa Sözlük Bilimi Derneği), 1988 yılında International Journal of Lexicography adıyla, AFRILEX (Afrika Sözlük Bilimi Derneği) de 1991 yılında Lexikos adıyla sözlük bilimine adanmış dergiler çıkarmaktadır. Her iki dergi de en saygın endekslerde (Arts and Humanities Citation Index, Social Sciences Citation Index vb.) taranmaktadır.

Türkiye'de ise sözlük ile ilgilenen Eskişehir Osmangazi Üniversitesi Sözlükbilimi Uygulama ve Araştırma Merkezi (SÖZMER), Hacettepe Üniversitesi Sözlük Bilimi Uygulama ve Araştırma Merkezi (HUSBAM) gibi üniversitelere bağlı kuruluşların yanında Türk Dil Kurumu (TDK) gibi ulusal çapta söz sahibi kurumlar bulunmaktadır. Bu kurumlar, “sözlük bilimi konusunda bilimsel araştırma ve uygulamalar yapmak; sözlük, sözlükçülük ve sözlükçe çalışmaları ile elde edilen bilimsel verilere ait veri tabanı oluşturarak, yazılım destekli yöntemlerle kullanıcıların hizmetine sunmak, Türkçe öğretiminin geçerli kaynaklara dayandırılmasını ve 
uluslararası bilim dili olarak geliştirilmesini sağlamak amacıyla kurulmuştur" (http://www.husbam.hacettepe.edu.tr/ Erişim Tarihi: 10.07.2019). Ancak, Türkiye'de sözlük bilimi ile ilgilenen farklı kurumlar olsa da Türk Dil Kurumunun ismi neredeyse sözlük ile özdeşleşmiştir. Bu kurumun, sözlük dendiğinde ilk akla gelen yer olması, sözlük araştırmaları başta olmak üzere, sözlüklerle ilgili uzun yıllardır tecrübesinin olması, yayınlar yapması ve bilimsel etkinliklere maddi destek sağlamasındandır. Özellikle 1990'lı yıllardan sonra kurumun sözlük ile ilgili çalışmaları büyük bir ivme yakalamıştır. Bu çalışmalar arasında "Türkçe Sözlük" önemli bir yer tutmaktadır. Kurum 1945 'te ilke kez yayımladığı bu eseri, gün geçtikçe içeriğini zenginleştirilerek baskı sayılarını arttırmıştır. Ayrıca sanal ortamda da "Güncel Türkçe Sözlük”, "Büyük Türkçe Sözlük" projeleriyle dünyadaki gelişmelere paralel çalışmaları Türkiye'de hayata geçirmiştir. Bunun yanında Türkiye Türkçesinin Tarihî Sözlükleri ve diğer Türk lehçelerinin sözlükleri ile ilgili yayınlar göz önünde bulundurulduğunda kurumun ne kadar önemli bir işlevi yerine getirdiği daha iyi anlaşılır (Baskın, 2014: 446).

Türk Dil Kurumunun sözlük üretmek dışında sözlük bilimine hizmeti, ürettiği süreli yayınlarla gerçekleşmektedir. Kurumun sözlük bilimine has bir süreli yayını olmasa da Türk Dili Dil ve Edebiyat Dergisi (Ekim 1951'den beri aylık), Türk Dili Araştırmaları Yıllığı Belleten (1953'ten beri altı ayda bir) ve Türk Dünyası Dil ve Edebiyat Dergisi (1996'dan beri altı ayda bir) adlı süreli yayınlarında sözlük bilimine dair pek çok çalışmaya yer verilmektedir.

\section{Amaç, Kapsam ve Yöntem}

\subsection{Amaç}

Herkese açı olan Türk Dil Kurumunun Süreli Yayınlar Veri Tabanında yer alan sözlük bilimi ile ilgili yazıların içerik analizlerinin yapılarak hangi sözlük bilimi durumuyla ilgili olduklarının ve kurumun hangi sözlüksel duruma ağırlık verdiğinin tespit edilmesi bu çalışmanın temel amacıdır. Bu, sözlük bilimi ile ilgilenen kişilerin yayınlar arasında kaybolmak yerine aradığı konuyu rahatlıkla bulmasını sağlayacak küçük ipuçları sunacaktır.

\subsection{Kapsam}

“Türk Dil Kurumunun süreli yayınlarından olan Türk Dili Araştırmaları Yillı̆̆g Belleten, Türk Dünyası Dil ve Edebiyat Dergisi ile Türk Dili Dil ve Edebiyat Dergisi bir veri tabanında toplanarak PDF biçiminde kullanıma sunulmuştur. Veri tabanında Türk Dili Araştırmaları Yıllığı Belleten'den 903, Türk Dünyası Dil ve Edebiyat Dergisi'nden 489 ve Türk Dili Dergisi'nden 20.038 olmak üzere toplam 21.430 yazı bulunmaktadır"3. Bu veri tabanında "sözlük / sözlüğü" sözcükleri tarandığında 233'sı Türk Dili Dil ve Edebiyat Dergisi'nde, 26 tanesi Türk Dili Araştırmaları Yılllğ 1 Belleten'te, 13 yazı da Türk Dünyası Dil ve Edebiyat Dergisi'nde olmak üzere toplam 272 yazının sözlük ile ilgili olduğu tespit edilmiştir. Sözlüklerle ilgili bu yazıların içerik

\footnotetext{
3. http://tdk.gov.tr/sureli-yayinlar-veri-tabani/ (erişim tarihi: 11.07.2019)
} 
analizleri yapılarak hangi sözlük durumuna ait olduğuna bakılmıştır. Sonra bunların dağılımları grafiklerle gösterilerek Türk Dil Kurumunun sözlüklerle ilgili süreli yayınlarında sözlük bilimi ile ilgili hangi konuların yer aldığı gösterilmiştir.

\subsection{Yöntem}

$\mathrm{Bu}$ araştırma doküman incelemesi ile gerçekleştirilmiştir. Doküman incelemesi, araştırmanın hedeflerine yönelik verilere ulaşmak için var olan belgelerin incelenmesi (Çepni, 2018) olarak tanımlanabilir. Bir nitel araştırman yöntemi olan doküman incelemesi, araştırılması hedeflenen olgu veya olgular hakkında bilgi içeren yazılı materyallerin analizini kapsamaktadır ${ }^{4}$. Bu çalışmada da Türk Dil Kurumunun süreli yayınlarının erişime açılan 21.430 yazısı incelenmiş, sözlük bilimi ile ilgisi tespit edilen 272'nin analizleri yapılarak sınıflandırılması sağlanmıştır. İçerik analizi yapılan yazılardan bir konu başlı̆̆ına dair yazı sayısı çok fazla ise bunların hepsinin gösterimi çok geniş yer tutacağından tümü yazılmamış, sadece durumu açıkça örnekleyen örneklere yer verilmiştir.

\section{Bulgular}

Türk Dil Kurumunun yayımladığ Türk Dünyası Dil ve Edebiyat Dergisi, Türk Dili Dil ve Edebiyat Dergisi) doğrudan sözlük ile ilgili değildir. Bu dergilerde dil ve edebiyat ile ilgili araştırmalar ve edebi ürünlerin (hikâye, şiir, söyleşi vb.) hepsi bir arada sunulmuştur. Bu üç derginin erişime açılan toplam yazı sayısı (25.07.2019 itibariyle) 21.430'dur. Bunların sadece 272'si sözlüklerle ilgilidir. Yani sözlükle ilgili yazılar, toplam yazıların içerisinde sadece \%1.26 oranında yer kaplamaktadır. Bu 1,26 oranındaki yazıların içerik analizleri yapıldı̆̆ında şu sonuçlarla karşılaşılmıştır:

\subsection{Sözlük veya sözlükle ilgili etkinliklere dair haberler}

Türk Dil Kurumunun dergilerinde yeni yazılan sözlükler, yeni bulunan tarihi sözlükler, sözlüklere dair toplantılar, sözlüklerin gelişimi gibi pek çok habere yer verilmiştir. Haber kategorisinde değerlendirilen yazıların bazı örnekleri şunlardır (Buradaki kaynak gösteriminde TDK'nin sanal ağ ortamındaki yazım biçimine sadık kalınarak gerçekleştirilmiştir):

Türk Dili Dil ve Edebiyat Dergisi, TDK. Haberler: Sinema Terimleri Sözlüğü Basımevine Verildi, Aralık 1962, C: XII, S: 135, s. 184

Türk Dili Dil ve Edebiyat Dergisi, TDK. Haberler: Gramer ve Sözlük Kollarının Yeni Başkanları, Kasım 1962, C: XII, S: 134, s. 130 (Bu yazıda, yeni oluşturulan Gramer ve Sözlük Kollarının yeni başkanlarının isimleri verilmiştir.)

\footnotetext{
${ }^{4}$.http://www.safakbasa.com.tr/yuklenen_akademik_calismalar/51-DOKUMAN_ANALIZI_(SUNUM).pdf (Erişim Tarihi: 10.07.2019).
} 
Türk Dili Dil ve Edebiyat Dergisi, TDK. Haberler: İlk Türkçe-Farsça Sözlük Tahran'da Basıldı, Aralık 1971, C: XXV, S: 243, s. 236 (Bu yazıda, ilk TürkçeFarsça sözlüğün Tahran'da basıldı̆̆ı haberi verilmiştir.)

Türk Dili Dil ve Edebiyat Dergisi, TDK. Haberler: Resulî Döneminden Kalma Bir Sözlük Bulundu, Aralık 1987, C: LIV, S: 432, s. 337 (Bu yazıda, Resuli döneminden kalma altı dilli bir sözlüğün bulunduğu haberi verilmiştir.)

Türk Dili Dil ve Edebiyat Dergisi, Parlatır, İsmail. Türkçe Sözlük Bilgisayar Ortamında, Ocak 1998, C: 1998/I, S: 553, s. 3-6 (Bu yazıda, Türkçe Sözlük'ün 1998 yılının başında hem yeni baskısıyla okurlarla buluşacağı, hem de daha geniş kitlelere ulaşmak için bilgisayar ortamında olacağı haberi verilmiştir.)

Türk Dili Dil ve Edebiyat Dergisi, Tezcan-Aksu, Belgin. Haberler: Uluslararası Sözlük Bilimi Sempozyumu, Temmuz 1999, C: 1999/II, S: 571, s. 652-656 (Bu yazıda, 20-21 Mayıs 1999 tarihinde Gazimağusa'da gerçekleştirilen sözlük bilimi sempozyumunun haberi verilmiş, hangi salonda, hangi konuların anlatıldığından bahsedilmiştir.)

Sözlükle ilgili yazıların 34’ü bu türdendir. Yani sözlük bilimi ile ilgili yazıların $\% 12.50$ 'si haberlerden ibarettir.

Türk Dil Kurumunun dergilerinde Türkiye dişında üretilen sözlükler, yurtdışındaki sözlük faaliyetlerine yönelik haberlere de yer verilmiştir. Dünyadaki sözlükler hakkında genel bir bilgi edinmek için önemli olan bu yazılardan bazıları şunlardır:

Türk Dili Dil ve Edebiyat Dergisi, Öneş, Ali Avni. Başka Dillerden Haberler: Indonezya Dili Üzerine; Endonezya'nın Singapur'a göndereceği Öğretmenler; Ana dilde dua; 4000 yıllık sözlük, Ocak 1962, C: XI, S: 124, s. 264-265

Türk Dili Dil ve Edebiyat Dergisi, Öneş, Ali Avni. Başka Dillerden Haberler: İlk Almanca-İndonezca Sözlük Hazırlandı; Alman dilinde Pakistan edebiyatı, Şubat 1962, C: XI, S: 125, s. 326

Türk Dili Dil ve Edebiyat Dergisi, Öneş, Ali Avni. Başka Dillerden Haberler: Önemli Bir Eser [Marcel Kohen]; Lâtincenin uluslararası dil olması isteniyor; İsrail' de Petrolle ilgili kelimeler İbraniceleştirildi, Şarap adları bile özleştirildi; Germen Dil ve Edebiyat Akademisi, Sağır - Dilsizler için sözlük, Ekim 1959, C: IX, S: 97, s. 33-35

Türk Dili Dil ve Edebiyat Dergisi, Rops, Daniel. Sözlüklere Övgü, çeviren: Ali Avni Öneş, Ağustos 1961, C: X, S: 119, s. 855-856

Türk Dili Dil ve Edebiyat Dergisi, Öneş, Ali Avni. Başka Dillerden Haberler: Fransız Radyosunda Dil Saati; Göçmen çocuklarına İbranice öğretmek için yeni metot; Yeni İngilizce-İbranice sözlük; Yabancı diller çok kolay öğrenilecek, İranlılar Pakistan'da Dil Enstitüsü Kuruyor, Haziran 1960, C: IX, S: 105, s. 470-471 
Türk Dili Dil ve Edebiyat Dergisi, Öneş, Ali Avni. Başka Dillerden Haberler:

Fransız Sözlük Ofisi; Yanlışsız bir gün; Akademi de temizliğe başladı;

Bilimler Akademisinde, Mayıs 1959, C: VIII, S: 92, s. 460-461

Türk Dil Kurumunun dergilerinde bu türden 11 yazı bulunmaktadır. Yani sözlük bilimi ile ilgili yazıların \%4.04'ü Türkiye dışında üretilen sözlükler, yurtdışındaki sözlük faaliyetlerine yönelik haberlerden oluşmaktadır.

Böylece sözlükler ve sözlük bilimi faaliyetleri ile ilgili haberlerin toplamı 45'tir. Bu da toplam yazılar içinde \%16,54'lük bir paya denk gelmektedir.

\subsection{Sözlüklerin içeriğine dair bilgiler veya sözlüklerden örnek metinler}

Türk Dili Dil ve Edebiyat Dergisi'nin 1974 yılında yayımlanan 279 sayısıyla başlayan ve toplam 24 sayıda devam eden Terim Sözlüklerimizden Örnekler başlı̆̆1 ile okurlara Türk Dil Kurumu tarafından yayımlanan terim sözlüklerinden birer sayfalık örnekler gösterilmiştir. Bu yazıların ilkinde şu açıklama bulunmaktadır: “Bilim, sanat ve uygulayım alanlarındaki kavramları, Türkçe sözcüklerle karşılama, hemen her dalda o dala özgü Türkçe terimler dizgesi yaratma Kurumumuzun ana amaçlarından biridir. Bu amaçla değişik bilim ve bilgi dallarındaki yetkili, uzman kişilerle işbirliği yapıyor, terimlerin Türkçeleştirilmesinde ortak bir çalışma sürdürüyoruz. Çalışmalarımızın verimlerini de ayrı ayrı sözcüklerde toplayıp yayımlıyoruz. Bundan böyle dergimizde, şimdiye değin yayımladığımız terim sözlüklerinden kimi örnekleri yabancı karşılıklarıyla birlikte sunacağız". Dergi sonraki sayılarda asalakbilim, ayaktopu, aydınlatma, budunbilim, eğitim, felsefe, gökbilim, toplumbilim vb. terim sözlüklerinin her birinden yaptığı alıntılardan 24 tane sözlük ile ilgili yazı oluşturmuştur.

Türk Dili Dil ve Edebiyat Dergisi, TDK. Terim Sözlüklerimizden Örnekler I [Mithat Enç: Ruhbilim Terimleri Sözlüğü], Aralık 1974, C: XXX, S: 279, s. 987 (Bu yazı, Ruhbilim Terimleri Sözlüğ̈̈'den alınan bazı maddelerden oluşmaktadır.

Türk Dili Dil ve Edebiyat Dergisi, TDK. Terim Sözlüklerimizden Örnekler X [Sedat Veyis Örnek: Budunbilim Terimleri Sözlüğü, Ekim 1975, C: XXXII, S: 289, s. 570 (Bu yazı, Sedat Veyis Örnek'in hazırladığı ve TDK tarafından yayımlanan Budunbilim Terimleri Sözlüğü'nün bir sayfasından oluşmaktadir.)

Benzer bir uygulama Güncel Türkçe Sözlük için yapılmıştır. Ali Püsküllüoğlu'nun Türk Dili Dil ve Edebiyat Dergisi'nde Güncel Sözlük - I adiyla Ocak 1975'te başlayan yazı serisi 8 sayıda devam etmiştir. Bu yazılarda Türkçe Sözlük'ten örnek sayfalara yer verilmiştir.

Türk Dili Dil ve Edebiyat Dergisi, Püsküllüoğlu, Ali. Güncel Sözlük - I, Ocak 1975, C: XXXI, S: 280, s. 63-65 
Türk Dili Dil ve Edebiyat Dergisi, Püsküllüoğlu, Ali. Güncel Sözlük - VIII, Ocak 1976, C: XXXIII, S: 292, s. 45-47

Yine diğer sözlüklerimizden çeşitli örnekleri içeren, bu eserleri tanıtmayı amaçlayan yazılara da yer verilmiştir. Bu yazılar genellikle bir dizi halinde değil tek bir yazı niteliğindedir ve diğerlerine nazaran daha geniştir. Örneğin Hasan Eren'in Türk Dilinin Etimolojik Sözlüğü (Örnekler) adlı çalışması bu türdendir.

Türk Dili Dil ve Edebiyat Dergisi, Eren, Hasan. Türk Dilinin Etimolojik Sözlüğü (Örnekler), Mayıs 1999, C: 1999/I, S: 569, s. 364-387

Türk Dil Kurumunun dergilerinde bu türden 41 yazı bulunmaktadır. Yani sözlük bilimi ile ilgili yazıların \%15.07'si sözlüklerin içeriğine dair bilgiler veya sözlüklerden örnek metinlerden oluşmaktadır.

\subsection{Türkçenin sözlüklerine bazı eklemelerin yapılmasına dair teklifler}

Türk Dil Kurumunun 1945 yılında yayımladığı ilk Türkçe Sözlük sadece 669 sayfadır. Ama Türkçe Sözlük'ünün 2011 yılında yapılan 11. baskısı 2224 sayfadır. İlk sekiz baskısını inceleyen Leyla Uzun'a göre Türkçe Sözlük her baskıda bir büyüme sağlamıştır (Uzun, 1999: 56). Bu büyüme, sözlük hazırlama ilke ve yöntemlerinden olduğu kadar derlenen, taranan veya teklif edilen söz varlığıyla sağlanmıştır. Sözlük için derlenen, taranan veya teklif edilen söz varlığının bir kısmı Türk Dil Kurumunun dergilerinde de yayımlanmıştır. Bir yöreden (Çukurova, Edirne, Eskişehir vb.) veya bir yazar / eserden alınan kimi sözcüklerin Türkçe Sözlük, Türk Dilinin Etimolojik Sözlüğü veya Derleme Sözlügü̈nün gelişimi için kullanılmasını teklif eden araştırmalardan bazıları şunlardır:

Türk Dili Araştırmaları Yıllığı Belleten, Eren, Hasan, Türk Dilinin Etimolojik Sözlüğüne Yeni Katkılar, 2002, C: I, s. 107-159.

Türk Dili Dil ve Edebiyat Dergisi, Hazar, Mehmet. Nevşehir Folkloru'ndan Derleme Sözlüğü'ne Katkılar, Eylül 2007, C: XCIV, S: 669, s. 580-584

Türk Dili Dil ve Edebiyat Dergisi, Öztürk, Erol. Mersin Yörüklerinden Derleme Sözlüğü'ne Katkılar, Mayıs 2009, C: XCVII, S: 689, s. 405-411

Türk Dili Dil ve Edebiyat Dergisi, Gözaydın, Nevzat. Çukurova'nın Söz Varlığından Türkçe Sözlük İçin Katkılar, Şubat 2011, C: C, S: 710, s. 153-159

Türk Dili Dil ve Edebiyat Dergisi, Gözaydın, Nevzat. Tanpınar'ın Sahnenin Dışındakiler ile Sözlüğümüze Katkıları, 2018, C: CXVII, S: 798, s.58-66.

Türk Dil Kurumunun dergilerinde bu türden 19 yazı bulunmaktadır. Yani sözlük bilimi ile ilgili yazıların \%6.98'i Türkçenin sözlüklerine bazı eklemelerin yapılmasına dair tekliflerden oluşmaktadır.

\subsection{Sözlük incelemeleri veya sözlüklerin birbiriyle karşılaştırılması}

Bu yazıların çoğu tanıtma ve değerlendirme amacı taşımaktadır. Bunların büyük bir bölümü birer deneme yazısıdır. Ancak bilimsel metotlara uygun yapılan eleştiri, 
değerlendirme ve tanıtmalar da mevcuttur. Deneme türündeki yazılarda genellikle "Bizce en şaşırtıcı olanı, başka bir ilginç durum, bizi eserin ciddiyeti ve mahiyeti konusunda ciddi şüphelere sevk etmektedir, böyle bir sözlük her evin kitaplığında yer alacaktır" gibi kişisel kanaatleri gösteren ifadeler yer almakta ve bu yazılarda genellikle kaynakça bulunmamaktadır. Bilimsel metotlara uygun yapılan eleştiri, değerlendirme ve tanıtmalar ise daha nesnel bir anlatıma ve anlatılanların desteklendiği kaynaklara sahiptir.

Türk Dünyası Dil ve Edebiyat Dergisi, Arıkoğlu, Ekrem, Mehmet Ölmez, Tuvaca, Dilbilgisi, Metinler, Sözlük, Simurg Yay., Ankara 1995, Bahar-1997, S: 3, s. 227-236.

Türk Dili Dil ve Edebiyat Dergisi, Özerdim, Sami N. Ansiklopedi - Sözlük [İbrahim Alâttin Gövsa: Resimli Yeni Lûgat ve Ansiklopedi], Şubat 1968, C: XVII, S: 197, s. 626-627

Türk Dili Dil ve Edebiyat Dergisi, Küçük, Murat. Yayın Dünyasından: Paşa Yavuzarslan, Osmanlı Dönemi Türk Sözlükçülüğü, Şubat 2011, C: C, S: 710, s. $178-186$

Türk Dili Araştırmaları Yıllığı Belleten, Ateş, Ahmed, Ali Şîr Nevâî́nin Arapça Sözlüğü Hakkında, [1988 (2.bs.)] 1957, s. 183-188.

Türk Dili Dil ve Edebiyat Dergisi, Dizdaroğlu, Hikmet. İncelemeler: İbn-i Melek ve Sözlüğü, Kasım 1957, C: VII, S: 74, s. 83-86

Türk Dünyası Dil ve Edebiyat Dergisi, Küçük, Murat, Kerkük Türkçesi Sözlüğü Üzerine, Yaz-2004, S: 18, s. 53-60.

Türk Dili Dil ve Edebiyat Dergisi, Özerdim, Sami N. Birkaç Kitap [Ruşen Alayloğlu - A. Ferhan Oğuzkan: Ansiklopedik Eğitim Sözlüğü; Cevdet Kudret: Ortaoyunu], (Kitaplar - Tenkit) Haziran 1976, C: XXXIII, S: 297, s. $482-483$

Türk Dili Araştırmaları Yıllığı Belleten, Doğan, İsmail, Kumuk ve Balkar Lehçeleri Sözlüğünün Bir Tahlili, [1994] 1990, s. 223-233.

Sözlüklerin veya sözlük içinde var olan bilgilerin birbiriyle kıyaslandığı yazıları da bu kapsamda değerlendirmek mümkündür. Örneğin Andreas Tietze'nin Tarihi ve Etimolojik Türkiye Türkçesi Lugatı'ndan bahsedililirken diğer etimolojik sözlüklerle karşılaştırılıp onun artı ve eksi yönlerine değinilmiştir. Türk Dil Kurumunun dergilerinde bu türden 92 yazı bulunmaktadır. Yani sözlük bilimi ile ilgili yazıların \%33.82'i sözlüklerin incelenmesi veya birbiriyle karşılaştırılması ile ilgilidir.

\subsection{Sözlükçülerin atışması / birbirlerini tenkit ettiği yazılar}

Sözlüklerin gelişmesinde eleştirinin oldukça mühim bir yeri vardır. Ancak Türkiye'de sözlük eleştirisi de eleştiri kültürü de gelişmemiştir. Türk Dil Kurumunun dergilerinde sözlük eleştirisi içeren yazılara bakıldığında bunların çoğunda "sözlük 
eleştirisinin karalamadan veya pohpohlamadan ibaret olduğu"(Boz, 2014: 32) açıç̧a görülür. Hatta sözlük eleştirisi adına yayımlanan bu yazıların çoğunda nezaket kurallarını zorlayan bir üslup mevcuttur. Okuyanlar, söz konusu yazıların ilgili olduğu eserin özelliklerinden ziyade, sözlüklerin yazarına veya diğer sözlükçülere öfkeyle yazılmış ironi veya hakaret içerikli ifadelerle karşılaşırlar. Bu yüzden sözlük eleştirisi addedilebilecek yazıların çoğunda eleştiri; bir eserin eksik, üstün, yanlış veya doğru yanlarını ortaya çıkarma aracı değil, karşı tarafa saldırma veya kendini savunma aracı olarak kullanılmıştır. Söz konusu yazılara şu örnekleri vermek mümkündür:

Türk Dili Dil ve Edebiyat Dergisi, Gökyay, Orhan Şaik. Beşik Uleması [Şevket Rado: Büyük Türk Sözlüğü], Mayıs 1970, C: XXII, S: 224, s. 94-109

Türk Dili Dil ve Edebiyat Dergisi, Parlatır, İsmail. Okul Sözlüğü Karşısında Tenkidin Sefaleti, Nisan 1995, C: 1995/I, S: 520, s. 323-336

Türk Dili Dil ve Edebiyat Dergisi, Zülfikar, Hamza. Okul Sözlügüünün Eleştirisi Üzerine, Ocak 1995, C: 1995/I, S: 517, s. 20-24

Türk Dili Dil ve Edebiyat Dergisi, Korkmaz, Zeynep. Prof. Dr. Talât Tekinin Gramer Terimleri Sözlüğü Üzerindeki Eleştirilerine Cevaplarımız: I, Eylül 1996, C: 1996/II, S: 537, s. 235-250

Türk Dili Dil ve Edebiyat Dergisi, Toparlı, Recep. En Büyük Sözlük mü? Yanlışlarla Dolu, Şişirilmiş Bir Sözlük mü?: Püsküllüoğlu Sözlüğü, Mart 2007, C: XCIII, S: 663, s. 195-206

Türk Dil Kurumunun dergilerinde bu türden 14 yazı bulunmaktadır. Yani sözlük bilimi ile ilgili yazıların \%5.14'ü sözlükçülerin birbirlerini tenkit ettiği metinlerden ibarettir.

\subsection{Sözlük içindeki bilgilerin kaynak olarak kabul (referans alındı̆̆g) edildiği yazılar}

Türk Dil Kurumunun dergilerinde sözlüklerde yer alan herhangi bir maddeye, madde başına ya da kavrama ait durumların incelendiği, değerlendirildiği veya referans alındığı çalışmalara da yer verilmiştir. Bu yazılarda sözlüksel verilere odaklanılmıştır. Veriler genellikle bilimsel bir yöntemle ele alınmış ve değerlendirilmiştir. Bu yazılarda sözlükler birer veri kaynağı olarak kullanılmıştır. Sözlüklerin tekniği veya yapısı üzerinde ise çok durulmamıştır.

Türk Dili Araştırmaları Yıllığı Belleten, Caferoğlu, A[hmet], Milletlerarası Kültür Sözlüğündeki Bazı Türkçe Unsurlar, 1969, s. 25-43.

Türk Dili Dil ve Edebiyat Dergisi, Gözaydın, Nevzat. Andreas Tietze'nin Sözlüğü ve Burun Üzerine, Eylül 2004, C: LXXXVIII, S: 633, s. 209-213

Türk Dili Araştırmaları Yıllığı Belleten, Yavuzarslan, Paşa, Sözlüklerde Sularında Kelimesi ve Kökeni, 2006, C: II, s. 139-148. 
Türk Dili Dil ve Edebiyat Dergisi, Torun, Yeter. Birinci Türk Dili Kurultayı ve Ceyhan Yörük A ğzı Kelimelerinin Derleme Sözlüğ̈̈'ndeki Kullanımları, Eylül 2007, C: XCIV, S: 669, s. 573-579

Türk Dili Araştırmaları Yıllığı Belleten, Öner, Mustafa, K[onstantin] K[uzmiç] Yudahin Sözlüğüne Göre Kırgızca Söz Varlığı, 2008, C: I, s. 101112.

Türk Dili Araştırmaları Yıllığı Belleten, Savran, Hülya, Derleme Sözlüğündeki Kalıplaşmış İsim-Fiillerin ve Sıfat-Fiillerin Yazı Dilinde Kullanilırlık Durumları, 2009, C: I, s. 51-92.

Türk Dili Dil ve Edebiyat Dergisi, Mayrhofer, Manfred. Bir Sanskrit Sözlükçüsünde Moğolca At İsimleri, Şubat 1984, C: XLVIII, S: 386, s. 115118

Türk Dil Kurumunun dergilerinde bu türden 19 yazı bulunmaktadır. Yani sözlük bilimi ile ilgili yazıların \%6.98' i sözlük içindeki bilgilerin kaynak olarak kabul (referans alındığı) edildiği çalışmalar niteliğindedir.

\subsection{Sözlük türleri, kullanımı, yapısı ve tarihçesi ile ilgili yazılar}

Türk Dil Kurumunun dergilerinde sözlük araştırmalarıyla ilgili önemli veriler de mevcuttur. Örneğin sözlüklerin kullanımı, yapısı veya tarihçesini ele alan bu yazılar bu türdendir. Türk sözlük biliminin gelişimi açısından değerli olan bu yazılardan bir kısmı şunlardır:

Türk Dili Dil ve Edebiyat Dergisi, Başkan, Özcan. Yabancı Dil Öğretimi: Dil Kullanımında Verimlilik Açısından Tikel Sözlükçe, Temmuz - Ağustos 1983, C: XLVII, S: 379-380, s. 136-145

Türk Dili Dil ve Edebiyat Dergisi, Parlatır, İsmail. Türkçe Sözlük Çalışmaları ve Sorunlarımız, Ocak 1995, C: 1995/I, S: 517, s. 3-19

Türk Dili Dil ve Edebiyat Dergisi, Göçer, Ali. Türk Dili İle İlgili Sözlüklere Genel Bir Bakış ve Günümüz İlköğretim Sözlükleri, Ekim 2001, C: 2001/II, S: 598 , s. $388-403$

Türk Dili Dil ve Edebiyat Dergisi, Karaağaç, Günay. Sözlük Yapısı, Ağustos 2001, C: 2001/II, S: 596, s. 120-127

Türk Dili Dil ve Edebiyat Dergisi, Cowie, A. P.. Uygulamalı Bir Dil Bilimi Alanı: Sözlük Bilimi, çeviren: Mesut Çetintaş, Ekim 2004, C: LXXXVIII, S: 634 , s. 580-588

Türk Dili Dil ve Edebiyat Dergisi, Akalın, Şükrü Halûk. Sözcük Bilimi ve Sözlükçülük, S. 698, Şubat 2010, s. 162-169

Türk Dili Dil ve Edebiyat Dergisi, Akalın, Şükrü Halûk. Sözlüğün Tarihi, C. XCVIII, S. 699, Mart 2010, s. 268-279. 
Türk Dil Kurumunun dergilerinde bu türden 30 yazı bulunmaktadır. Yani sözlük bilimi ile ilgili yazıların \%11.02'si sözlük türleri, kullanımı, yapısı ve tarihçesi ile ilgili araştırmalardan oluşmaktadır.

\subsection{Sözlüklere emek verenlerin vefat haberleri}

Türk Dili Dil ve Edebiyat Dergisi'nde Yitirdiklerimiz köşesinde, yaşarken sözlüklere emek vermiş Türkçenin önemli şahsiyetlerinin vefat haberleri verilmiştir. Bu haberlerde kişilerin yaşamöyküsü ve sözlüklere katkıları anlatılmıştır. Örneğin "Sözlükçü İlhan Ayverdi" yazısında İlhan Ayverdi'nin hayatı anlatıldıktan sonra "Onun Türkçeye en önemli hizmeti, Kubbealtı Vakfının yayımlamaya karar verdiği; 1971'de hazırlığına, 1976'da da yazımına başlanan Misalli Büyük Türkçe Sözlük'ün çalışmalarını üstlenmesidir. 13. yüzyıldan günümüze Türk dilinin gelişimini ortaya koyan bu sözlük, 34 yıllık bir çalışmanın sonucunda 2004 yılında tamamlanarak ertesi yıl üç cilt hâlinde İstanbul'da yayımlandı." bilgisi verilerek sözlük adına yaptığı hizmetlere değinilmiştir. Bu yönüyle Yitirdiklerimiz köşesi sadece bir vefat bildirme yeri değil, ölen kişilerin sözlük ile ilgili çalışmalarını hatırlatma ve gösterme yeri olması bakımından önemlidir.

Türk Dili Dil ve Edebiyat Dergisi, Tan, Nail. Yitirdiklerimiz: Sözlükçü İlhan Ayverdi, Aralık 2009, C: XCVII, S: 696, s. 755-756

Türk Dili Dil ve Edebiyat Dergisi, Tan, Nail. Yitirdiklerimiz: Sözlükçü, Hikâyeci, Romancı ve Şair Ş. Hulki Aktunç, Ağustos 2011, C: CI, S: 716, s. $181-183$

Türk Dili Dil ve Edebiyat Dergisi, Tan, Nail. Yitirdiklerimiz: Sözlükçü, Sinema Tarihçisi Ali Nijat Özön, Ocak 2011, C: C, S: 709, s. 80-81

Türk Dili Dil ve Edebiyat Dergisi, Tan, Nail. Yitirdiklerimiz: Sözlükçü, Yayımcı Aydın Sami Güneyçal, Mart 2012, C: CII, S: 723, s. 281-284

Türk Dili Dil ve Edebiyat Dergisi, Tan, Nail. Yitirdiklerimiz: Şair, Sözlükçü, Türkçe-Edebiyat Ders Kitapları Yazarı Arif Hikmet Par, Mart 2012, C: CII, S: 723 , s. $285-288$

Türk Dil Kurumunun dergilerinde bu türden 5 yazı bulunmaktadır. Yani sözlük bilimi ile ilgili yazıların \%1.83'i sözlüklere emek verenlerin vefat haberlerinden oluşmaktadır.

\subsection{Sözlüğe katkısı olanlara övgü yazıları}

Türk Dili Dil ve Edebiyat Dergisi'nde Yitirdiklerimiz köşesindekine benzer olmasına rağmen içeriği biraz farklı olan ve ölüm haberinden ziyade, sözlüklere emek vermiş Türkçenin önemli şahsiyetlerinin anıldığı, faaliyetlerinin tanıtıldığı, övgü dolu sözlerin yer aldığı bu yazıların bir kısmı şöyledir: 
Türk Dili Dil ve Edebiyat Dergisi, Eren, Hasan. Ananiasz Zajaczkowski Özel Bölümü: Ananiasz Zajaczkowski ve Kıpçakça Sözlükler Alanındaki Çalışmaları, Haziran 2000, C: 2000/I, S: 582, s. 564-573

Türk Dili Dil ve Edebiyat Dergisi, Uçarol, Tuncer. Behçet Necatigil'in Sözlükleri, Mart 1980, C: XLI, S: 342, s. 181-183

Türk Dili Dil ve Edebiyat Dergisi, Demiray, Kemal. Sözlükçülüğümüzde Önemli Bir Aşama ve Kamûs-1 Türkî, Temmuz 1981, C: XLIII, S: 355, s. 2326

Türk Dil Kurumunun dergilerinde bu türden 3 yazı bulunmaktadır. Yani sözlük bilimi ile ilgili yazıların \%1.10 sözlüğe katkısı olanların anıldığı ve övüldüğü metinlerdir.

\subsection{Sözlüklerle doğrudan ilgili olmayan yazılar}

Bu tür veri taramalarında sistem, başlıkları taramaktadır. Bu yüzden "sözlük/sözlüğü" kelimesini içeren her başlık listelenir. Ancak bunların bir kısmı sözlüklerle ilgili olmayabilir. Bu türden yazılara şunlar örnek gösterilebilir:

Türk Dünyası Dil ve Edebiyat Dergisi, Çelik, Neşe, Hamza Zülfikar, Türkçede Ses Yansımalı Kelimeler (İnceleme-Sözlük), TDK Yay.: 628, Ankara 1995, VII+699 s., Güz-1997, S: 4, s. 236-252.

Türk Dili Dil ve Edebiyat Dergisi, Akant, Özlem. Değerlendirmeler: Mustafa Özkan: Mahmûd bin Kâdî-i Manyâs-Gülistan Tercümesi Giriş, İnceleme, Metin, Sözlük, (Kitaplar - Tenkit) Şubat 1995, C: 1995/I, S: 518, s. 200-202

Türk Dili Araştırmaları Yıllığı Belleten, Tezcan, Semih, @Marzubân-nâme Tercümesi॰ Üzerine ( Prof. Dr. Zeynep Korkmaz Şadru'd-din Şeyhoğlu, Marzubân-nâme Tercümesi, İnceleme-Metin-Sözlük-Tıpkıbasım. DTCF Yayınları 219, 460 s. + CXXXVII tıpkıbasım, Ankara, 1973.), [1978] 1977, s. 413-431.

Türk Dil Kurumunun dergilerinde bu türden 3 yazı bulunmaktadır. Yani sözlük bilimi ile ilgili yazıların \%1.10'u sözlük kelimesinin içinde bulunduğu bir başlı̆ga sahip olduğu halde doğrudan sözlüklerle ilgili olmayan metinlere aittir.

\subsection{Dizgi hatalarından dolayı sözlük yazıları ile birlikte görünen yazılar}

Türk Dil Kurumunun dergilerinin veri tabanında bazı dizgi hataları bulunmaktadır. $\mathrm{Bu}$ taramada -c-/-1- harflerinin bazen birbirinin yerine kullanıldığ 1 tespit edilmiştir. $\mathrm{Bu}$ yüzden aslında sözcük olan başlıktaki kelimeler sözlük olarak yazıldı̆̆ 1 için listelenmiş bir yazı bulunmaktadır.

Türk Dili Dil ve Edebiyat Dergisi, Üstünova, Kerime. Dede Korkut Destanlarında İki Sözcüklü Yüklemler, Şubat 1998, C: 1998/I, S: 554, s. 140146 
çalışması,

Türk Dili Dil ve Edebiyat Dergisi, Üstünova, Kerime. Dede Korkut Destanlarında İki Sözlüklü Yüklemler, Şubat 1998, C: 1998/I, S: 554, s. 140146

olarak kayıtlarda yer almaktadır. Bu da incelenen yazıların \%0.36'sına denk gelmektedir.

\section{Sonuç, Tartışma ve Öneriler}

Elbette bu yazıların içeriği daha alt basamaklara ayırmak ve incelemek mümkündür. Ancak burada Türk Dil Kurumunun süreli yayınlarında yer alan sözlük bilimi yazılarının mahiyeti hakkında genel bir tablo çizilmesi amaçlandığından sınıflandırılma da genel hatlarla yapılmıştır. Türk Dil Kurumu, kurulduğu günden bu zamana kadar Türk dili ve kültürü için oldukça mühim işler yapmıştır. Kurum, kendi işlerini daha bilimsel bir zeminde gerçekleştirebilmek adına Derleme Tarama Kolu, Sözlük Kolu, Terim Kolu, Yayın Kolu gibi çalışma grupları oluşturmuştur. Sözlük Kolu da "Türkçe sözlük, imlâ kılavuzu, okul sözlükleri ve başka dillerden Türkçeye çeşitli sözlükler hazırlayan veya hazırlatan bir koldur"5". "Yoğun çabalar sonucunda ilk sözlük çalışmasının 1945'te yapılmasıyla beraber sözlük çalışmaları da hız kazanmıştır. Özellikle 1970’li yıllardan sonra sözlük çalışmalarında belirgin bir artış görülmüş ve bu, yıldan yıla artmıştır. 1980'li yıllardan sonra sözlük çalışmaları daha da yoğunluk kazanmış; öyle ki aynı yılda çok sayıda sözlük yayımlanmış; bazı sözlükler aynı yıl içerisinde birden fazla baskı yapmıştır" (Dursunoğlu, 2011: 270). Bu sözlükler arasında Türk Dil Kurumunun Türkçe Sözlük'ünün önemli bir yeri vardır. 1945 yılından sonra sürekli geliştirilmiş ve yayımlanmaya devam etmiştir. Ancak ülkemizde sözlük çalışmaları sadece Türk Dil Kurumu tarafından yapılan çalışmalarla sınırlı kalmamıştır. Diğer bazı kuruluşların bünyesinde de sözlükler hazırlanmıştır. Özellikle Dil Derneği, Kubbealtı Kültür ve Sanat Vakfı, Yapı Kredi Yayınları ve Adam Yayınlarının çıkarttıkları sözlükler de (Böler, 2006: 103) Türk sözlük geleneği açısından önemlidir. Yine sözlük faaliyetlerini bu matbu ve genel sözlüklerle sinırlandırmamak gerekir. Okul sözlükleri, terim sözlükleri, resimli sözlükler, elektronik sözlükler gibi birbirinden oldukça farklı ve çok sayıda sözlük üretilmiştir. Bütün bu sözlük çeşitleri sözlük biliminin sadece belli bir kısmını oluşturur. Bu sözlüklere dair veri toplama, yöntem önerme, kullanım bilgisi sunma, kullanıcı görüşlerini öğrenme, maliyet ve saha analizleri gerçekleştirme gibi sözlüklerle doğrudan veya dolaylı pek çok çalışma da sözlük biliminin içindedir. Türk Dil Kurumu sözlük yayımladı̆̆ı gibi sözlükle ilgili bu çalışmaları da süreli yayınları vasıtasıyla yayımlamıştır.

Türk Dil Kurumunun süreli yayınlarında sözlüklerle, dolayısıyla sözlük bilimi ile ilgili hemen her türden içeriğe sahip yazı bulmak mümkündür. Sözlüklerin tarihi, sözlük biliminin gelişimi, eski ve yeni sözlüklerin içeriği, sözlük metinleri, sözlüklerin

\footnotetext{
${ }^{5}$. http://turkoloji.cu.edu.tr/ANSIKLOPEDI/tdk.php, (Erişim Tarihi: 10.05.2019)
} 
kullanımı, sözlük tenkitleri vb. konular yayımlanmıştır. Bu yazıların konularına gör dağılımı Grafik 1'de gösterilmiştir.

Sözlük Bilimi ile İlgili Yazıların Sayısı

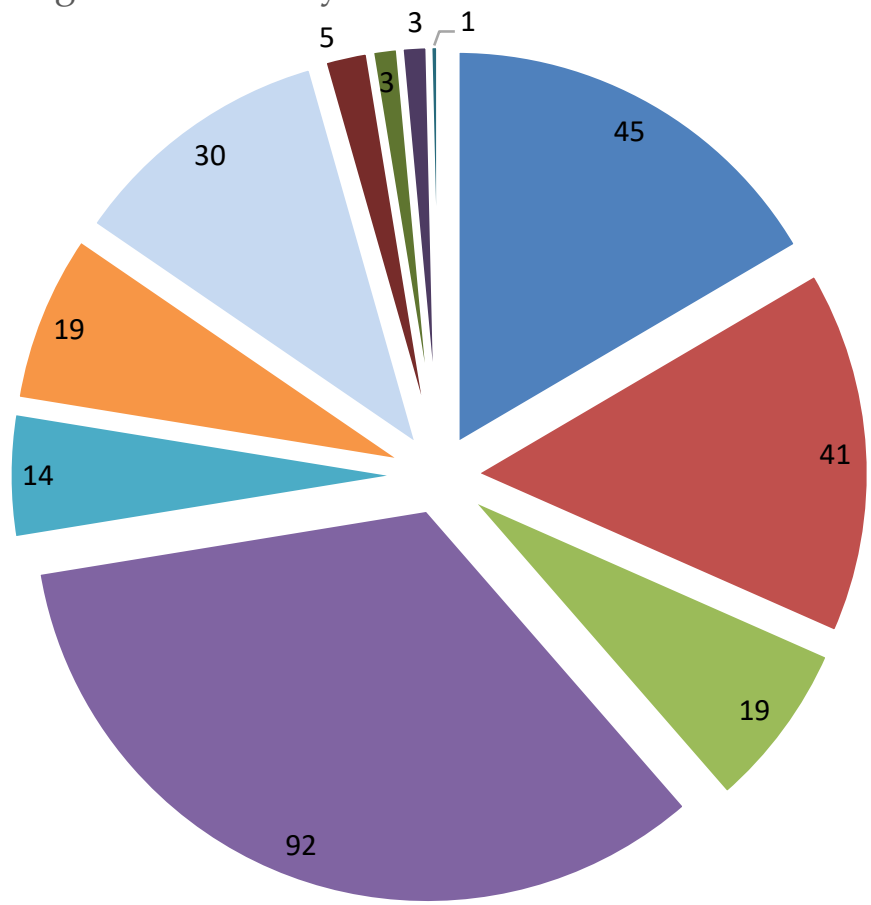

- Sözlük veya sözlükle ilgili etkinliklere dair haberler

- Sözlüklerin içeriğine dair bilgiler veya sözlüklerden örnek metinler

- Türkçenin sözlüklerine bazı eklemelerin yapılmasına dair teklifler

- Sözlük incelemeleri veya sözlüklerin birbiriyle karşılaştırılması

- Sözlükçülerin atışması / birbirlerini tenkit ettiği yazılar

• Sözlük içindeki bilgilerin kaynak olarak kabul (referans alındığı) edildiği yazılar

घ Sözlük türleri, kullanımı, yapısı ve tarihçesi ile ilgili yazılar

- Sözlüklere emek verenlerin vefat haberleri

- Sözlüğe katkısı olanlara övgü yazıları

- Sözlüklerle doğrudan ilgili olmayan yazılar

- Dizgi hatalarından dolayı sözlük yazıları ile birlikte görünen yazılar

Grafik 1. Türk Dil Kurumunun süreli yayınlarında sözlüklerle ilgili konuların dağ̊lımı 
Türk Dil Kurumunun süreli yayınlarında sözlük bilimi ile ilgili konuların yüzdelik dağılımı şöyledir:

\section{Sözlük bilimi ile ilgili yazıların yüzdelik dağılımları}

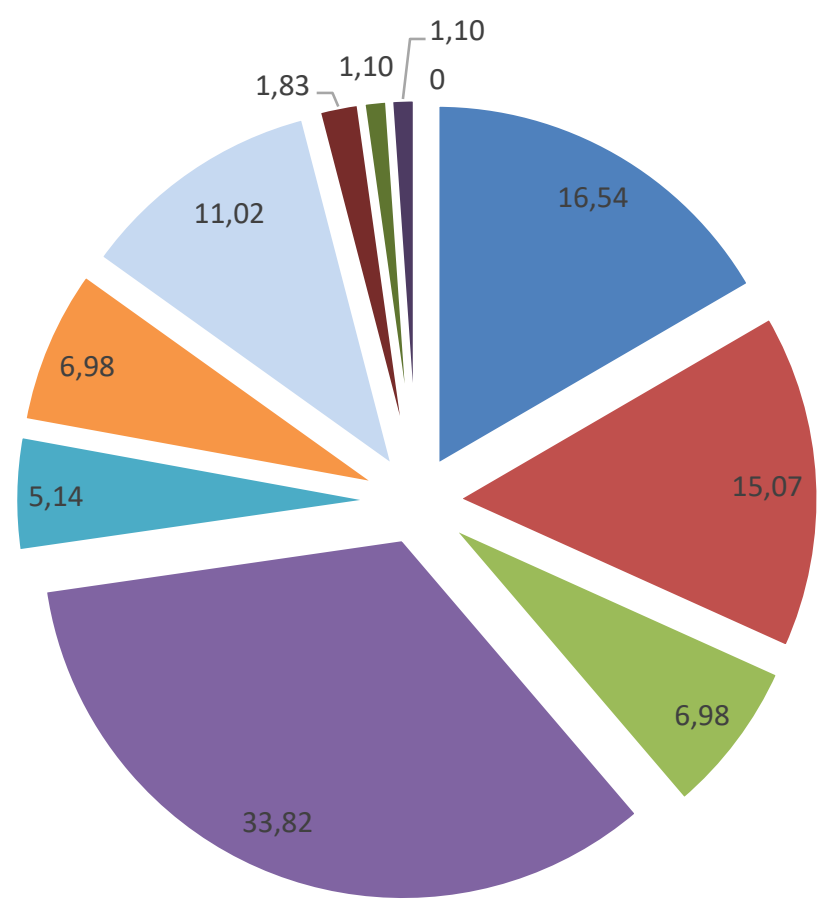

- Sözlük veya sözlükle ilgili etkinliklere dair haberler

- Sözlüklerin içeriğine dair bilgiler veya sözlüklerden örnek metinler

- Türkçenin sözlüklerine bazı eklemelerin yapılmasına dair teklifler

- Sözlük incelemeleri veya sözlüklerin birbiriyle karşılaştırılması

- Sözlükçülerin atışması / birbirlerini tenkit ettiği yazılar

- Sözlük içindeki bilgilerin kaynak olarak kabul (referans alındığı) edildiği yazılar

• Sözlük türleri, kullanımı, yapısı ve tarihçesi ile ilgili yazılar

- Sözlüklere emek verenlerin vefat haberleri

- Sözlüğe katkısı olanlara övgü yazıları

- Sözlüklerle doğrudan ilgili olmayan yazılar

- Dizgi hatalarından dolayı sözlük yazıları ile birlikte görünen yazılar

Grafik 2. Türk Dil Kurumunun süreli yayınlarında sözlük ile ilgili konuların yüzdelik dağılımı

Sözlük bilimi ile uluslararası düzeyde ilgilenen pek çok kurum vardır. Bunlar genellikle bulundukları kıta içinde örgütlenmiş ve uğraş alanları kıta sınırlarını aşmış kurumlardır. Örneğin Dictionary Society of North America (DSNA, kuruluşu 1975), European Association for Lexicography (EURALEX, kuruluşu 1983), Australian Association for Lexicography (AUSTRALEX, kuruluşu 1990), and the African Association for Lexicography (AFRILEX, kuruluşu 1995) (Tono, 2014: 1) bunlardandır. 
Bunların yanında Southeast Asian Lexicography (SeaLex), Spanish Association for Lexicography (Fontenelle, 2008: 2) gibi ulusal veya daha dar çevreye sahip örgütlenmeler mevcuttur. Bu kurumların hemen hepsinin düzenli yayımlana sözlük bilimi yayınları (süreli yayınları) mevcuttur. Türkiye' de bu düzeyde sözlük bilimi ile uğraşan bir kurum yoktur. Ancak Türk Dil Kurumu kurulduğu günden beri sözlük çalışmalarına büyük ehemmiyet vermiştir. Hatta Türkiye'de sözlük ve Türk Dil Kurumunun adı neredeyse özdeşleşmiştir. Bu kurumun, yayımladığı sözlüklerin çeşidi çoktur ayrıca sözlük konusunda otorite kurumdur. Ancak kurumun sözlük bilimi ile ilgili bir süreli yayını bulunmamaktadır. Özellikle 1980'lerden sonra sözlük hazırlamanın yanında sözlük araştırmalarının (sözlük kullanımı, sözlük-kullanıcı ilişkisi, sözlük tarihi, sözlük hazırlama teknikleri ve yöntemleri vb.) oldukça yaygınlaştığı düşünüldüğünde Türkiye'de bu çalışmaları yayımlamak ve duyurmak konusunda kurum geç kalmıştır. Diğer yayınlar arasında sözlük bilimi yazılarını da yayımlamak bu konuya ilgi duyan araştırmacıları ve okurları denizin içine atmak demektir. Cumhuriyetten sonra Türk dili ve sözlüğü adına önemli çalışmalar yapan bu Türk Dil Kurumunun sözlük kolunun bağımsız bir yapıya dönüştürülmesi ve dünyadaki muadillerinin yaptığı faaliyetleri yürütmesi Türk sözlük biliminin gelişmesi açısından önemlidir. Zira buradaki bilgi birikiminin bir üst evreye taşınması gerekmektedir. Bu yeni kurum, sözlük bilimi içerikli süreli yayınların üretilmesi; sözlük bilimi toplantı; çalıştay ve sempozyumlarının düzenlenmesi; çağa uygun sözlüklerin üretilmesi; sözlük bilimi konusunda çalışanların desteklenmesi vb. çalışmaları ivediyle yapmalıdır. Zira Türkiye'de sözlük bilimi yayınları yok denecek kadar azdır, sözlükler de dünyadaki benzerlerinin çok gerisinde kalmıştır. Çağdaş bilgi seviyesine erişmek ve Türkçe sözlüklerinin evrensel niteliklere ulaşması için daha çok yayın yapılmasının önü açılmalıdır.

\section{Kaynakça}

Akalın, Ş. H. (2010). Sözlüğün tarihi, Türk Dili Dil ve Edebiyat Dergisi, C. XCVIII, 699, 268-279.

Baskın, S. (2014). Türkiye ve dünyada sözlük bilimi: tanımı, kapsamı ve diğer bilimlerle ilişkisi, International Journal of Language Academy, 2/4, 445-457.

Boz, E. (2014). Değişen sözlük kültürümüz, Türk Dili, 746, 30-33.

Böler, T. (2006). Türkçe sözlük (TDK) ile örnekleriyle Türkçe sözlük'ü (MEB) karşılaştırma denemesi. Sosyal Bilimler Araştırmaları Dergisi, 1, (2006): 101-118

Çepni, S. (2018). Araştırma ve Proje Çalışmalarına Giriş, Yazarın Kendi Yayını, 8. Baskı. Trabzon 
Dursunoğlu, H. (2011). Cumhuriyet döneminde yapılan sözlük çalışmaları ve Türkçe sözlükler üzerine bir kaynakça denemesi, Dumlupınar Üniversitesi Sosyal Bilimler Dergisi, 31, 255-272.

Fontenelle, T. (2008). Introduction, Practical Lexicography-A Reader-, (edt. by Thierry Fontenelle), Oxford University Press Inc, New York

Jackson, H. (2002). Lexicography an introduction, London and New York: Routledge.

Tono, Y. (2014). Lexicography in Asia: its future and challenges, Lexicography, 1, 1-5.

Uzun, L. (1999). 1945'ten bu yana Türkçe sözlükler, Kebikeç, 7-8, 53-59.

\section{Elektronik Kaynaklar}

http://turkoloji.cu.edu.tr/ANSIKLOPEDI/tdk.php, Erişim Tarihi: 10.05.2019

http://tdk.gov.tr/sureli-yayinlar-veri-tabani/, (Erişim Tarihi: 11.07.2019

https://sozmer.ogu.edu.tr/ (Erişim Tarihi: 10.07.2019)

http://www.husbam.hacettepe.edu.tr/ (Erişim Tarihi: 10.07.2019)

http://tdk.gov.tr/category/yayinlar/yayinlar-yayinlar/ (Erişim Tarihi: 10.07.2019) 